\title{
THE CRYSTAL STRUCTURE AND QUANTUM MECHANICAL TREATMENT OF THE ANTI-CANCER AGENT FLAVOPIRIDOL (HYDROCHLORIDE) AND THE CHROMONE ALKALOID ROHITUKINE
}

\author{
J. WILSON QUAIL ${ }^{1}$ and ROBERT A. GOSSAGE ${ }^{2 *}$ \\ ${ }^{1}$ Saskatchewan Structural Sciences Centre, University of Saskatchewan, \\ 110 Science Place, Saskatoon, Saskatchewan S7N 5 C9 \\ ${ }^{2}$ Department of Chemistry \& Biology, Ryerson University, \\ 350 Victoria Street, Toronto, Ontario M5B $2 \mathrm{~K} 3$
}

\begin{abstract}
The characterisation of the solid-state crystal structure of the hydrochloric acid salt of anti-cancer agent Flavopiridol (i.e., (-)-2-(2-chlorophenyl)5,7-dihydroxy-8-[(3S,4R)-3-hydroxy-1-methyl-4-piperidinyl]-4H-1benzopyran-4-one) is described. The title compound forms meta-stable $\mathrm{X}$-ray quality crystals by slow evaporation of solutions of the material in aqueous methanol. The crystalline unit cell contains two organic cations, two formal chloride counterions and two molecules of methanol, one of which is replaced in $20 \%$ occupancy by a water molecule. The crystal form is of space group $P 1$ with cell parameters $a=7.2014(10) \AA, b=$ 12.0094(9) $\AA, c=12.6581(14) \AA, \alpha=89.146(4)^{\circ}, \beta=89.788(6)^{\circ}$ and $\gamma$ $=82.180(4)^{\circ}$. The unit cell volume is $1084.4(2) \AA^{3}$. The general structural features of individual (gas-phase) molecules of protonated Flavopiridol and the naturally occurring 2-methyl-[4H]-chromen-4-one analogue Rohitukine have been calculated by application of Density Functional Theory (DFT) at the $\mathrm{B} 3 \mathrm{LYP} / 6-31 \mathrm{G}^{*}$ level of sophistication. These results are compared to the reported solid-state data of these two biologically relevant flavanoids.
\end{abstract}

\section{INTRODUCTION}

Flavanoids are a class of natural products that are widely distributed in the biosphere, particularly in the plant kingdom (Harborne \& Mabry, 1982), as primarily secondary metabolites. Many flavanoids are, not surprisingly, biologically active and hence have been the subject of intense scrutiny by natural products chemists and the pharmaceutical industry (Eisnor et al., 2006; Joule et al., 1995). These investigations

* Author to whom correspondence should be addressed: gossage@ryerson.ca 
have led to the identification of a vast number of potential new sources of phytochemicals that have been used or are under development as both nutraceuticals and/or chemotherapy agents. In addition, novel structural motifs derived from natural products often serve as starting points or "leads" for compounds that are investigated for their clinical potential. Many years ago, the flavanoid compound dubbed Rohitukine (1: Scheme 1), which contains a 2-methyl-[4H]-chromen-4-one frag-
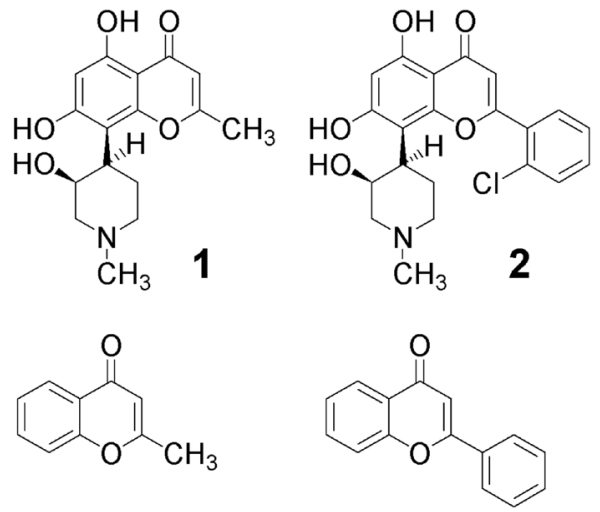

Scheme 1 Schematic representations of Rohitukine (1) and Flavopiridol (2). Below these pictorials are the parent structures of 2-methyl-[4H]-chromen-4-one and flavone: left and right, respectively.

ment, was isolated (Harmon et al., 1979) from the Asian plant Amoora rohituka (Syn. Aphanamixis polystachya) (meliaceae). This alkaloid incorporates both the aforementioned chromone skeleton, a common organic motif (Joule et al., 1995), and an unusual modified piperidinyl ring system. Rohitukine itself displays a range of biological activities including its ability to modulate immune response systems and act as an anti-inflammatory agent (Naik et al., 1998; Sedlacek et al., 1996). However, it is most noteworthy for its potent anti-cancer potential. Large quantities of $\mathbf{1}$ can be obtained from Dysoxylum binectariferum (Yang et al., 2004; Mohanakumara et al., 2010), which is currently the primary natural source of this chromone, although two species of Schumanniophyton also produce 1 (Houghton, 2002; Houghton \& Hairong, 1987; Houghton \& Woldemariam, 1993). Chemical modification of the basic structure of $\mathbf{1}$ has led to the synthesis of a more biologically active flavone (Harborne \& Mabry, 1982) derivative given the name Flavopiridol (2: 2-[2-chlorophenyl]-5,7-dihydroxy- 
8-[\{3S,4R\}-3-hydroxy-1-methyl-4-piperidinyl]-4H-1-benzopyran-4one: Scheme 1). This compound has already entered Phase III clinical trials for applications against a number of classes of cancer including breast, colon and lung cancers, leukaemia and cancers of the head and neck (Billard et al., 2003; Carlson et al., 1996; Fischer \& Lane, 2000; Kitada et al., 2000; Lin \& Porcu, 2004; Patel et al., 1998; Wu et al., 2002). The mode(s) of action of $\mathbf{2}$ have been identified as primarily due to the ability of the compound to act as a selective kinase inhibitor and thus it represents the first such inhibitor to enter clinical trials (Bishop et al., 2001; Byrd et al., 1998; Carlson et al., 1996; Fabbro et al., 2002; Filigueira et al., 1996 \& 2002; Huwe et al., 2003; Kitada et al., 2000; König et al., 1997; Kryŝtof \& Strnad, 2003; Noble et al., 2004; Patel et al., 1998; Pepper et al., 2003; Sedlacek, 2001; Sedlacek et al., 1996; Senderowicz et al., 1999; Senderowicz \& Sausville, 2000; Takada \& Aggarwal, 2004; Wang \& Ren, 2010). A brief report of the characterisation of $\mathbf{1}$, via single crystal X-ray diffraction methods, has been previously reported (Yang et al., 2003) but details of the structure (bond lengths, bond angles, etc.) were not disclosed. Flavopiridol has not been investigated in this way. Neither $\mathbf{1}$ nor $\mathbf{2}$ have been structurally examined from a theoretical perspective by quantum mechanical methods. In this report, dedicated to the $150^{\text {th }}$ anniversary of the Nova Scotian Institute of Science, we disclose the characterisation of the hydrochloric acid salt of $\mathbf{2}$ by X-ray diffraction methods and compare the solid-state structures of both $\mathbf{1}$ and $\mathbf{2}$ to those obtained by examining the molecules via quantum mechanical methods, specifically employing Density Functional Theory (DFT) at the в3LYр/6-31G* level of theory (Goodman, 1998; Koch \& Holthausen, 2002; Sholl \& Steckel, 2009).

\section{METHODS}

Flavopiridol hydrochloric acid salt (i.e., Alvocidib) was kindly supplied to the authors by Sanofi-Aventis, Inc. Caution! Flavopiridol is a potent biologically active agent and therefore should only be handled by qualified personnel using strict laboratory safety protocols. Crystals of the material were obtained by dissolving approximately $25 \mathrm{mg}$ of the compound in methanol $(\sim 10 \mathrm{~mL})$ and then allowing the resulting solution, contained in a small vial, to slowly evaporate under ambient conditions. Yellow rectangular shaped crystals were obtained after a period of about 7 days. These meta-stable crystals remain intact for a 
period of about 6 weeks before returning to a powder form of (presumably) solvent-free material.

$\mathrm{X}$-ray diffraction data was collected at $-100^{\circ} \mathrm{C}$ on a Nonius Kappa CCD diffractometer, using the COLLECT program (Nonius, 1998). Cell refinement and data reductions used the programs DENZO and SCALEPACK (Otwinowski \& Minor, 1997). SIR97 (Altomare et al., 1999) was used to solve the structure and SHELXL97 (Sheldrick, 2008) was used to refine the structure. ORTEP-3 for Windows (Farrugia, 1997) was used for molecular graphics (Figure 1) and PLATON (Spek, 2001) was used to prepare material for publication. H atoms were placed in calculated positions with $U_{i s o}$ constrained to be 1.2 times $U_{e q}$ of the carrier atom for all hydrogen atoms. The structure solution has two cations and two chloride ions in the asymmetric unit. In addition, there are two solvent methanol molecules in the asymmetric unit, one with disorder. Twenty percent of one methanol is replaced by a water molecule. Modelling the disorder proved to be difficult because of the strong coupling between the occupancy factors and the thermal factors. In the end, the occupancy of water was set at 0.20 and the methanol at 0.80 to stabilize the refinement. The only B ALERT is for possible higher symmetry. This test does not consider the disordered atoms. Since one methanol is disordered with a water molecule and the other is not, higher symmetry is not possible. Crystallographic data (excluding structure factors) have been deposited in the Cambridge Crystallographic Data Centre as Supplementary publication No. CCDC 832180. Copies of these data can be obtained free of charge on application to CCDC, 12 Union Road, Cambridge CB2 1EZ, U.K. (fax: +44 1223 336 033; e-mail: deposit@ ccdc.cam.ac.uk).

Density Functional Theory was used for the quantum mechanical calculations employing the $\mathrm{B} 3 \mathrm{LYP} / 6-31 \mathrm{G}^{*}$ level of theory (Becke, 1993; Lee et al., 1988); these data were obtained by using the SPARTAN 10.0 (Spartan,2010) suite of programs. These calculations included neutral 1 and the cationic $N$-protonated form of Flavopiridol (i.e., $[\mathbf{2 + H}]^{+}$). Zero point energy calculations were performed on the idealised structures to ensure that the data reflect true minima along the potential energy surface and hence no negative IR or Raman frequencies were calculated. Details of these data (including .mol files) are available from the authors on request. 

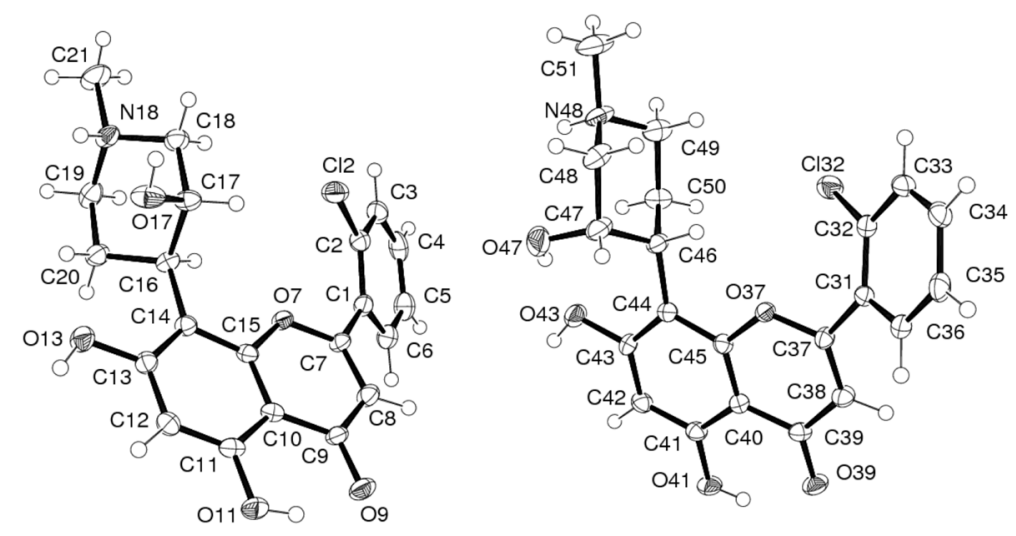

Fig 1 ORTEP representation of the two independent cations of $[2+\mathrm{H}]$ found in the unit cell; cation A (left) and cation B (right).

\section{RESULTS AND DISCUSSION}

The general crystal data parameters for the $\mathrm{HCl}$ salt of $\mathbf{2}$ (i.e., $[\mathbf{2}+\mathrm{H}]$ $\mathrm{Cl}$ ) can be found in Table 1. A list of selected bond lengths, bond and torsion angles for $[2+\mathrm{H}] \mathrm{Cl}$, in addition to the computationally derived gas phase values of both $\mathbf{1}$ and cationic $[\mathbf{2}+\mathrm{H}]^{+}$, are displayed in Table 2 . Molecular representations (ORTEP) of the two independent $[2+\mathrm{H}]$ cations found within the unit cell are shown in Figure 1. In many respects, the solid-state structure of the cation of $\mathbf{2}$ is very similar to that described for other structurally characterised flavones with quite typical bond lengths and angles, specifically with respect to the benzopyrone and aromatic ring systems (Allen et al., 1987). 5-Hydroxyflavones, such as the title material, typically display intra-molecular $H$-bonding between the $\mathrm{H}$ atom on ring position-5 and the carbonyl O-atom (Chou et al., 2002; Krishnaiah et al., 2005; Parvez et al., 2001; Shoja 1989, 1990; Watson et al., 1991) and this certainly appears to be evident here $(\mathrm{O} 9 \mathrm{H} \bullet \bullet \mathrm{O}=1.856 \AA)$. The benzopyrone ring is essentially planar with a torsion angle of less than $3^{\circ}$, similar to other flavones that have been previously reported (e.g., Krishnaiah et al., 2005) and this also appears to be the case for Rohitukine (Yang et al., 2003). For simplicity, direct comparisons will be noted for unit cell Molecule A only. Details of Molecule B can be found in the appropriate .cif file and/or details noted in Table 2 . The overall crystal motif reveals considerable 
Table 1 General crystal data for compound $(2+\mathrm{HCl})_{2} \cdot(\mathrm{MeOH})_{1.80} \bullet\left(\mathrm{H}_{2} \mathrm{O}\right)_{0.20}$

\begin{tabular}{|c|c|}
\hline Parameter: & $(2+\mathrm{HCl})_{2} \bullet(\mathrm{MeOH})_{1.80} \cdot\left(\mathrm{H}_{2} \mathrm{O}\right)_{0.20}$ \\
\hline$\underline{\text { Formula }}$ & $\mathrm{C}_{43.80} \mathrm{H}_{49.60} \mathrm{~N}_{2} \mathrm{O}_{12} \mathrm{Cl}_{4}$ \\
\hline fw & 937.85 \\
\hline Crystal size $(\mathrm{mm})$ & $0.25 \times 0.20 \times 0.13$ \\
\hline $\mathrm{a}(\AA)$ & $7.2014(10)$ \\
\hline$\overline{b(\AA)}$ & $12.0094(9)$ \\
\hline $\mathrm{c}(\AA)$ & $12.6581(14)$ \\
\hline$\alpha\left(^{\circ}\right)$ & $89.146(4)$ \\
\hline$\beta\left({ }^{\circ}\right)$ & $89.788(6)$ \\
\hline$\gamma\left({ }^{\circ}\right)$ & $82.180(4)$ \\
\hline $\mathrm{V}\left(\AA^{3}\right)$ & $1084.4(2)$ \\
\hline $\mathrm{D}_{\text {calc }}\left(\mathrm{g} / \mathrm{cm}^{3}\right)$ & 1.436 \\
\hline Crystal system; space group & Triclinic; P1 \\
\hline $\mathrm{Z}$ & 1 \\
\hline $\mathrm{F}(000)$ & 490.4 \\
\hline $\mathrm{T}(\mathrm{K})$ & $173(2)$ \\
\hline Absorption coefficient $\left(\mathrm{mm}^{-1}\right)$ & 0.339 \\
\hline $2 \theta$ range $\left({ }^{\circ}\right)$ & $2.86-27.63$ \\
\hline Limiting indices & $-9 \leq \mathrm{h} \leq+9 ;-15 \leq \mathrm{k} \leq+15 ;-16 \leq 1 \leq+16$ \\
\hline Reflections collected & 15962 \\
\hline Reflections unique & $8544[\mathrm{R}(\mathrm{int})=0.0414]$ \\
\hline 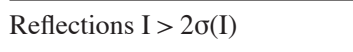 & 8544 \\
\hline Restraints / Parameters & $3 / 571$ \\
\hline GOF on $\mathrm{F}^{2}$ & 1.055 \\
\hline Final R indices $\mathrm{I}>2 \sigma(\mathrm{I})$ & $\mathrm{R}_{1}=0.0422 ; \mathrm{wR}_{2}=0.0911$ \\
\hline $\mathrm{R}$ indices (all data) & $\mathrm{R}_{1}=0.0522 ; \mathrm{wR}_{2}=0.0987$ \\
\hline$\varrho_{\text {min,max }}\left(\mathrm{e} \cdot \AA^{3}\right)$ & $0.269,-0.284$ \\
\hline Abs. Structure Parameter & $-0.01(4)$ \\
\hline$\lambda(\AA)$ & $0.71073 \mathrm{Mo} \mathrm{K} \alpha$ \\
\hline
\end{tabular}


Table 2 Selected bond lengths $(\AA)$, bond and torsion angles $\left(^{\circ}\right)$ measured for $[2+\mathrm{HCl}]_{2} \bullet(\mathrm{MeOH})_{1.80} \cdot\left(\mathrm{H}_{2} \mathrm{O}\right)_{0.20}$ and calculated (DFT: B3LYP/6-31G*) for $\mathbf{1}$ and $[2+\mathrm{H}]^{+}$. Estimated standard deviations are shown in parentheses.

\begin{tabular}{|c|c|c|c|}
\hline Value & 1 (calc.) & {$[2+\mathrm{H}]^{+} .($calc. $)$} & {$[2+\mathrm{H}] \mathrm{Cl} \cdot(\text { observed })^{\mathrm{a}}$} \\
\hline $\mathrm{C}=\mathrm{O}(\AA)$ & 1.251 & 1.243 & $1.263(4) ; 1.269(3)$ \\
\hline $\mathrm{C}=\mathrm{C}(\AA)$ & 1.351 & 1.346 & $1.343(4) ; 1.358(4)$ \\
\hline $\mathrm{C}_{\text {aromatic }}-\mathrm{OH}(\AA)$ & $1.339 ; 1.359$ & $1.330 ; 1.363$ & $\begin{array}{l}1.360(3) ; 1.364(4) \\
1.358(3) ; 1.368(3)\end{array}$ \\
\hline C-Cl (Å) & $\mathrm{n} / \mathrm{a}$ & 1.761 & $1.737(3) ; 1.741(3)$ \\
\hline $\mathrm{C}=\mathrm{C}-\mathrm{CH}_{3}\left(^{\circ}\right)$ & 126.2 & $\mathrm{n} / \mathrm{a}$ & $\mathrm{n} / \mathrm{a}$ \\
\hline $\mathrm{C}=\mathrm{C}-\mathrm{C}_{\text {phenyl }}\left({ }^{\circ}\right)$ & $\mathrm{n} / \mathrm{a}$ & 124.84 & $125.4(3) ; 125.6(3)$ \\
\hline $\mathrm{C}-\mathrm{CH}-\mathrm{CH}-\mathrm{OH}\left({ }^{\circ}\right)$ & 56.13 & -77.10 & $-66.4(3) ;-63.6(4)$ \\
\hline $\mathrm{C}=\mathrm{C}-\mathrm{C}-\mathrm{CCl}\left({ }^{\circ}\right)$ & $\mathrm{n} / \mathrm{a}$ & 106.42 & $-143.0(3) ; 141.3(3)$ \\
\hline
\end{tabular}

${ }^{a}$ Entries for Molecule A (see text) are listed first.

intermolecular $\mathrm{H}$-bonding aspects, specifically the 7-OH group with a formal chloride anion $(\mathrm{O} 13 \mathrm{H} \bullet \bullet \mathrm{Cl}=2.23 \AA)$. The $\mathrm{N}-\mathrm{H}$ functionality is also in close proximity to one of the lattice methanol $\mathrm{O}$ atoms $(\mathrm{N} 18 \mathrm{H} \bullet \bullet \mathrm{O}$ $=1.96 \AA$ ). The chlorophenyl group is oriented out of the plane of the benzopyrone ring by about $41^{\circ}$; a property which decreases the contact distance between the $\mathrm{Cl}$ atom and the $\mathrm{H}$ on piperidinyl ring position 3' $(\mathrm{C} 17 \mathrm{H} \cdot \bullet \bullet \mathrm{Cl}=2.86 \AA)$. Other flavones (Hall et al., 2001; Waller et al., 2005), including 2'-substituted examples, also display such large angles (Chou et al., 2002; Shoja, 1989; Ting et al., 1972) and indeed a value of $62^{\circ}$ has been reported for 6-hydroxy-2',3'-dimethoxyflavone (Wallet et al., 1993).

Flavopiridol hydrochloride obviously demonstrates considerable inter- and intra-molecular $H$-bonding, as detailed above, in the solidstate. The obvious low volatility of this salt negates one's ability to also examine this material in the gas-phase to evaluate any $H$-bonding facets. However, the examination of compounds from a theoretical perspective allows one to probe the structural aspects of such species in the hypothetical gas-phase (i.e., a single isolated molecule). Of the plethora of computational methods that can be used in this regard, Density Functional Theory (DFT) has become a widely employed and powerful tool to examine molecules and molecular fragments from a theoretical point of view in the gas-phase, solution and indeed even in network solids (Goodman, 1998; Koch \& Holthausen, 2002; Sholl 
$\&$ Steckel, 2009). An examination of both $\mathbf{1}$ and $[\mathbf{2}+\mathrm{H}]^{+}$was therefore carried out using DFT to examine the overall structural properties and attempt to draw some conclusions about possible gas-phase structures of these two species. Selected calculated bond lengths and bond and torsion angles can be found in Table 2. As expected (Chojnacka et al., 2011), the DFT calculations do closely parallel the solid-state structures of the two materials. As details of the bond lengths and angles for the crystalline state of $\mathbf{1}$ do not appear in the literature (Yang et al., 2003), a comparison of calculated $\mathbf{1}$ to that of $[2+\mathrm{H}]^{+}$depicts a reasonable structural similarity between the two species (Table 2). As inter-molecular $\mathrm{H}$-bonding cannot be involved here, this restricts the attractive forces to those of an intra-molecular nature. A skeletal diagram indicating the calculated $H$-bonding aspects (dashed line 'bonds') is shown in Scheme 2. The calculated Flavopiridol cation displays lesser rotation of the aromatic group with respect to that of the benzopyrone ring (calc. $106^{\circ}$; found $141^{\circ}$ ) and this serves to facilitate $H$-bonding between the $3^{\prime}-\mathrm{OH}$ (piperdinyl) group and the chlorine atom (calc. $\mathrm{O} 17 \mathrm{H} \bullet \bullet \mathrm{Cl}=2.65 \AA$ ). Obviously, this latter result causes considerable rotation of the piperdinyl ring and this again strengthens intra-molecular $H$-bonding, in this case between the same-OH and the benzopyrone ether $\mathrm{O}$ atom $(\mathrm{O} 17 \mathrm{H} \bullet \bullet \bullet \mathrm{O} 7=2.05 \AA)$. These latter aspects do not appear for 1 but instead strong interactions between the piperonyl $\mathrm{OH}$ and the benzopyrone $7^{\prime}-\mathrm{OH}$ position is observed $(\mathrm{O} 17 \mathrm{H} \bullet \bullet \mathrm{O}=$ 1.88 A: Table 2; Scheme 2). Not surprisingly, both calculated structures include close contacts between the $\mathrm{H}$ atom on ring position- 5 and the

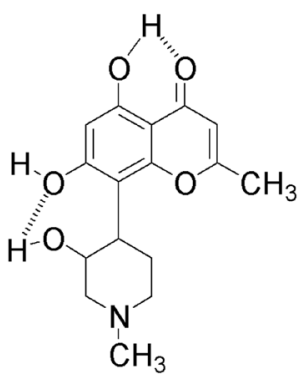

[1]

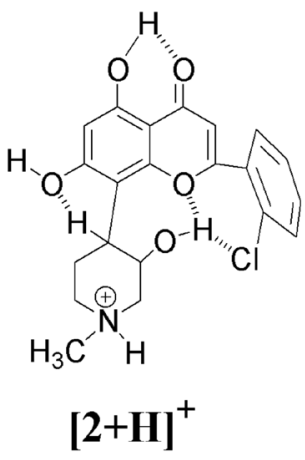

Scheme 2 Schematic representation of the H-bonds (dashed lines) calculated for gasphase 1 and the Flavopiridol cation $\left([2+\mathrm{H}]^{+}\right)$. In both cases, stereochemical bond descriptors have been removed for clarity. 
carbonyl O-atom although a slight over estimation of this strength is noted (calc. $\mathrm{O} 11 \mathrm{H} \bullet \bullet \cdot \mathrm{O} 9=1.69 \AA$ for 1 and $1.70 \AA$ for $[2+\mathrm{H}]^{+}$). The $\mathrm{C}=\mathrm{O}$ (1: $1.25 \AA ; 2: 1.24 \AA)$ and $\mathrm{C}-\mathrm{Cl}$ bonds $\left([2+\mathrm{H}]^{+}\right)$are well-estimated in both cases $(2$ : $\mathrm{C}-\mathrm{Cl}=1.76 \AA)$. The calculated UV-Visible absorptions are also estimated with fair accuracy for both $\mathbf{1}\left(\lambda_{\max }\right.$ [calc.]: $241 \mathrm{~nm}$; $\lambda_{\max }$ : [observed]: $\left.252 \mathrm{~nm}\right)$ and $[2+\mathrm{H}] \mathrm{Cl}\left(\lambda_{\max }\right.$ [calc.]: $247 \mathrm{~nm} ; \lambda_{\max }$ : [observed: aqueous]: $269 \mathrm{~nm}$ ), despite the molecular rearrangements noted above for gas-phase calculations (Sedlacek et al., 1996; Tang et al., 2004; Yang et al., 2009).

\section{CONCLUSIONS}

The solid-state crystal structure of Flavopiridol hydrochloride, in the form of meta-stable crystals containing both methanol and water molecules, has been detailed. This compound has features similar to other related flavanoids that have been characterised in the solid-state such as Rohitukine. This latter material and the cationic component of the title compound have been further examined from a theoretical perspective by Density Functional Theory and these results suggest a modified pattern of $H$-bonding for individual gas-phase molecules.

Acknowledgements The author is indebted to Ryerson University for support of this work. Additional funding for the author has been provided by NSERC (Canada) in the form of a Discovery Grant. Prof. D.-M. Ren (Shandong University) is thanked for providing a reprint of his publication. Prof. Daniel A. Foucher (Ryerson University) is acknowledged for his critical review of this manuscript, as well as anonymous journal referees.

\section{REFERENCES}

Allen, F.H., Kennard, O., Watson, D.G., Brammer, L., Orpen, A.G., \& Taylor, R. (1987) Tables of bond lengths determined by X-ray and neutron diffraction. Part 1. Bond lengths in organic compounds. J Chem Soc Perkin Trans II S1-S19.

Altomare, A., Burla, M.C., Camalli, M., Cascarano, G., Giacovazzo, C., Guagliardi, A., Moliterni, A.G.G., Polidori, G., \& Spagna, R. (1999) SIR97: a new tool for crystal structure determination and refinement. J Appl Cryst 32:115-119.

Becke, A.D. (1993) Anew mixing of Hartree-Fock and local density-functional theories. J Chem Phys 98:1372-1377. 
Billard, C., Kern, C., Tang, R., Ajchenbaum-Cybalista, F., \& Kolb, J.-P. (2003) Flavopiridol downregulates the expression of both the inducible NO synthase and $\mathrm{p} 27^{\mathrm{kip} 1}$ in malignant cells from B-cell chronic lymphocytic leukemia. Leukemia 17:2435-2443.

Bishop, A.C., Buzko, O., \& Shokat, K.M. (2001) Magic bullets for protein kinases. Trends Cell Biol 11:167-172.

Byrd, J.C., Shinn, C., Waselenko, J.K., Fuchs, E.J., Lehman, T.A., Nguyen, P.L., Flinn, I.W., Diehl, L.F., Sausville, E., \& Grever, M.R. (1998) Flavopiridol induces apoptosis in chronic lymphocytic leukemia cells via activation of caspase- 3 without evidence of bcl-2 modulation or dependence on functional p53. Blood 92:3804-3816.

Carlson, B.A., Dubay, M.M., Sausville, E.A., Brizuela, L., \& Worland, P.J.(1996) Flavopiridol induces $\mathrm{G}_{1}$ arrest with inhibition of cyclin-dependent kinase (CDK) 2 and CDK4 in human breast carcinoma cells. Cancer Res 56:2973-2978.

Chojnacka, M.W., Lough, A.J., Wylie, R.S., \& Gossage, R.A. (2011) Piperonylic anhydride: isolation and conformational analysis by X-ray crystallography and density functional theory calculations. J Mol Struct 991:158-161.

Chou, N.H.-H., Parvez, M., Ali, M.S., Ahmed, S., \& Ahmed, W. (2002) Cirsimaritin. Acta Cryst E58:o285-o287.

Eisnor, C.E., Gossage, R.A., \& Yadav, P.N. (2006) Oxazoline chemistry. Part 11: synthesis of natural and synthetic isoflavones, stilbenes and related species via $\mathrm{C}-\mathrm{C}$ bond formation promoted by a Pd-oxazoline complex. Tetrahedron 62:3395-3401.

Fabbro, D., Ruetz, S., Buchdunger, E., Cowan-Jacob, S.W., Fendrich, G., Liebetanz, J., Mestan, J., O'Reilly, T., Traxler, P., Chaudhuri, B., Fretz, H., Zimmermann, J., Meyer, T., Caravatti, G., Furet P., \& Manley, P.W. (2002) Protein kinases as targets for anticancer agents: from inhibitors to useful drugs. Pharma Therap 93:79-98.

Farrugia, L.J. (1997) ORTEP-3 for Windows - a version of ORTEP-III with a graphical user interface (GUI). J Appl Cryst 30:568.

Filgueira de Azevedo, Jr., W., Canduri, F., Freitas da Silveira, N.J. (2002) Structural basis for inhibition of cyclin-dependent kinase 9 by flavopiridol. Biochem Biophys Res Commun 293:566-571.

Filgueira de Azevedo, Jr., W., Mueller-Dieckmann H.-J., SchulzeGahmen U., Worland, P.J., Sausville, E., \& Kim,S.-H. (1996) Structural basis for specificity and potency of a flavonoid inhibitor of human CDK2, a cell cycle kinase. Proc Natl Acad Sci USA 93:2735-2740.

Fischer, P.M., \& Lane, D.P. (2000) Inhibitors of cyclin-dependent kinases as anti-cancer therapeutics. Curr Med Chem 7:1213-1245.

Goodman, J.M. (1998) Chemical Applications of Molecular Modelling; Royal Society of Chemistry: Cambridge, U.K.

Hall, B.J., Hanrahan, J.R., Johnston, G.A.R., Hambley, T.W., \& Hibbs, D.E. (2001) 6-Methoxyflavone. Acta Cryst E57:0592-0593.

Harborne, J.B., \& Mabry, T.J. (1982) The Flavanoids: Advances in Research; Chapman \& Hall: New York, U.S.A.; Ch. 10. 
Harmon, A.D., Weiss, U., \& Silverton, J.V. (1979). The structure of rohitukine, the main alkaloid of Amoora rohituka (Syn.Aphanamixispolystachya) (meliaceae). Tetrahedron Lett 20:721-724.

Houghton, P.J. (2002) Chromatography of the chromome and flavonoid alkaloids. J. Chromatogr A 967:75-84.

Houghton, P.J. \& Hairong, Y. (1987) Further chromone alkaloids from Schumanniophyton magnificum. Planta Med 262-264.

Houghton, P.J. \& Woldemariam, T.Z. (1993) High-performance liquidchromatographic analysis of chromone alkaloids from Schmanniophyton species. Phytochem Anal 4:9-13.

Huwe, A., Mazitschek, R., \& Giannis, A. (2003) Small molecules as inhibitors of cyclin-dependent kinases. Angew Chem Int Ed 42:2122-2138.

Joule, J.A., Mills, K., Smith, G.F. (1995) Heterocyclic Chemistry, $3^{\text {rd }}$ Edition; Chapman \& Hall: New York, U.S.A.; Ch. 9.

Kitada, S., Zapata, J.M., Andreeff, M., \& Reed, J.C. (2000) Protein kinase inhibitors flavopiridol and 7-hydroxy-staurosporine down-regulate antiapoptosis proteins in B-cell chronic lymphocytic leukemia. Blood 96:393-397.

Koch, W., \& Holthausen, M.C. (2002) A Chemist's Guide to Density Functional Theory: $2^{\text {nd }}$ Edition, Wiley-VCH, Toronto.

König, A., Schwartz, G.K., Mohammad, R.M., Al-Katib, A., \& Gabrilove, J.L. (1997) The novel cyclin-dependent kinase inhibitor flavopiridol downregulates bcl-2 and induces growth arrest and apoptosis in chronic B-Cell leukemia lines. Blood 90:4307-4312.

Krishnaiah, M., Kumar, R.R., Kumar, N.J., Gunasekar, D., \& Jayaprakasam, B. (2005) 5-Hydroxy-7,8,2'-trimethoxyflavone. Acta Cryst E61:o2862-o2864.

Kryštof, V., \& Strnad, M. (2003) Inhibitory cyklin-dependentních kinas. Chem Listy 95:295-300.

Lee, C., Yang, W., \& Parr, R.G. (1988). Development of the Colle-Salvetti correlation-energy formula into a functional of the electron density. Phys Rev B 37:785-789.

Lin, T.S., \& Porcu, P. (2004) Flavopiridol: where do we stand in chronic lymphocytic leukemia? Leukemia 18:243-246.

Mohanakumara, P., Sreejayan, N., Priti, V., Ramesha, B.T.,Ravikanth, G.,Ganeshaiah, K.N.,Vasudeva,R.,Mohan,J.,Santhoshkumar, T.R., Mishra, P.D., Ram, V., \& Shaanker, R.U. (2010) Dysoxylum binectariferum Hook.f (Meliaceae), a rich source of rohitukine. Fitoterapia 81:145-148.

Naik, R.G., Kattige, S.L., Bhat, S.V., Alreja, B., de Souza, N.J., \& Rupp, R.H. (1988) An anti-inflammatory cum immunomodulatory piperidinylbenzopyranone from Dysoxlum binectariferum: isolation, structure and total synthesis. Tetrahedron 44:2081-2086.

Noble, M.E.M., Endicott, J.A. \& Johnson, L.N. (2004) Protein kinase inhibitors: insights into drug design from structure. Science 303:1800-1805.

Nonius, b.v. (1998) COLLECT. Nonius, b.v., Delft, The Netherlands. 
Otwinowski, Z., \& Minor, W. (1997) Processing X-ray diffraction data collected in oscillation mode. Macromolecular Crystallography: Part A in Methods in Enzymology (Eds.: Carter, C. W., \& Sweet, R. M.) 276:307-326.

Parvez, M., Riaz, M., \& Malik, A. (2001) Eupatorin. Acta Cryst E57:0289-0291.

Patel V., Senderowicz, A.M., Pinto, Jr., D., Igishi, T., Raffield, M., Quintanilla-Martinez, L., Ensley, J.F., Sausville, E.A. \& Gutkind, J.S. (1998) Flavopiridol, a novel cyclin-dependent kinase inhibitor, suppresses the growth of head and neck squamous cell carcinomas by inducing apoptosis. J Clin Invest 102:1674-1681.

Pepper, C., Thomas, A., Fegan, C., Hoy T., \& Bentley P. (2003) Flavopiridol induces apoptosis in B-cell chronic lymphocytic leukaemia cells through a 38 and ERK MAPkinase-dependent mechanism. Leuk Lymphoma 44:337-342.

Sedlacek, H.H. (2001) Mechanisms of action of flavopiridol. Crit Rev Oncol/ Hematol 38:139-170.

Sedlacek, H.H., Czech, J., Naik, R., Kaur, G., Worland, P., Losiewicz, M., Parker, B., Carlson, B., Smith, A., Senderowicz, A., \& Sausville, E. (1996) Flavopiridol (L86 8275; NSC 649890), a new kinase inhibitor for tumor therapy. Int J Oncol 9:1143-1168.

Senderowicz, A.M. (1999) Flavopiridol: the first cyclin-dependent kinase inhibitor in human clinical trials. Invest New Drugs 17:313-320.

Senderowicz, A.M., \& Sausville, E.A. (2000) Preclinical and clinical development of cyclin-dependent kinase modulators. J Natl Cancer Inst 92:376-387.

Sheldrick, G.M. (2008) A short history of shelX. Acta Cryst A64:112-122.

Shoja, M. (1989) 5-Hydroxy-7-methoxyflavone. Acta Cryst C45:828-829.

Shoja, M. (1990) 5-Hydroxyflavone. Acta Cryst C46:517-519.

Sholl, D.S., \& Steckel, J.A. (2009) Density Functional Theory: A Practical Introduction, Wiley \& Sons, Toronto.

Spek, A.L. (2001) Platon. Utrecht University, The Netherlands.

Spartan 10.0. (2010) Wavefunction Inc., Irvine CA.

Takada Y., \& Aggarwal B.B. (2004) Flavopiridol inhibits NF-KB activation induced by various carcinogens and inflammatory agents through inhibition of I $x \mathrm{~B} \alpha$ kinase and p65 phosphorylation. J Biol Chem 279:4750-4759.

Ting, H.-Y., Watson, W.H., \& Domínguez, X.A. (1972) The molecular structure of 3',5,5',6-tetramethoxyflavone, $\mathrm{C}_{19} \mathrm{H}_{18} \mathrm{O}_{6}$. Acta Cryst B28:10461051.

Wang, L.-M., \& Ren, D.-M. (2010) Flavopiridol, the first cyclin-dependent kinase inhibitor: recent advances in combination chemotherapy. Mini-Rev Med Chem 10:1058-1070.

Waller, M.P., Hibbs, D.E., Overgaard, J., Hanrahan, J.R., \& Hambley, T.W. (2003) Flavone. Acta Cryst E59:0767-o768.

Wallet, J.-C., Gaydou, E.M., Mas, M., Molins, E., \& Miravitlles, C. (1993) 2-(2,3-Dimethoxyphenyl)-6-hydroxy-4H-1-benzopyran-4-one (6-hydroxy-2',3'-dimethoxyflavone). Acta Cryst C49:2030-2032. 
Watson, W.H., Kashyap, R.P., Gao, F., \& Mabry, T.J. (1991) Structure of the flavone Hymenoxin. Acta Cryst C47:459-461.

Wu, K., Wang, C., D’Amico, M., Lee, R.J., Albanese, C., Pestell, R.G., \& Mani S. (2002) Flavopiridol and Trastuzumab synergistically inhibit proliferation of breast cancer cells: association with selective cooperative inhibition of cyclin D1-dependent kinase and Akt signalling pathways. Mol Cancer Therap 1:695-706.

Yang, D.H., Cai, S.Q., Zhao, Y.Y., \& Liang, H. (2003) Determination of the absolute configuration of Rohitukine. Chin Chem Lett 14:720-723.

Yang, D.H., Cai, S.Q., Zhao, Y.Y. \& Liang, H. (2004) A new alkaloid from Dysoxylum binectariferum. J Asian Nat Prod Res 6:233-236.

Yang, X., Zhao, X., Phelps, M.A., Piao, L., Rozewski, D.M., Liu, Q., Lee, L.J., Marucci, G., Grever, M.R., Byrd, J.C., Dalton, J.T., \& Lee, R.J. (2009) A novel liposomal formulation of flavopiridol. Int J Pharmaceutics 365:170-174. 
